\title{
KEBIJAKAN PENGELOLAAN HUTAN DAN KEMISKINAN MASYARAKAT (STUDI KASUS DI NAGARI GARABAK DATA DAN NAGARI BUKIK KANDUANG, KABUPATEN SOLOK) ${ }^{1}$
}

\author{
Hidayatul Fajri ${ }^{2}$
}

\begin{abstract}
This study discusses forest management by local communities and society of Nagari Garabak Data and Nagari Bukik Kanduang Solok Regency of West Sumatra Province. Nagari Garabak Data is a village located in a protected forest area with the acquisition entirely in the hands of the state while in Nagari Bukik Kanduang forest is managed and controlled by people with a form of community forests (communal forest). Principal argument of this study that differences in the management model of the village causing differences in poverty communities. The purpose of this research is to understand forest management in both villages and analyze the impact of the forest management against poverty.
\end{abstract}

Key Word: Forest Management, Poverty Peoples, Ulayat, Access

\begin{abstract}
ABSTRAK
Penelitian ini membahas tentang pengelolaan hutan yang dilakukan oleh masyarakat Nagari ${ }^{3}$ Garabak Data dan masyarakat Nagari Bukik Kanduang Kabupaten Solok Provinsi Sumattera Barat. Nagari Garabak Data merupakan nagari yang berada di dalam kawasan hutan lindung dengan penguasaan sepenuhnya di tangan negara sedangkan hutan di Nagari Bukik Kanduang di kelola dan dikuasai oleh masyarakat dengan bentuk hutan masyarakat (hutan ulayat). Argumen pokok dari penelitian ini yaitu perbedaan model pengelolaan di kedua nagari menyebabkan terjadinya perbedaan kemiskinan masyarakatnya. Tujuan penelitian ini adalah untuk memahami pengelolaan hutan di kedua nagari dan menganalisa dampak dari pengelolaan hutan tersebut terhadap kemiskinan masyarakat.
\end{abstract}

Kata Kunci: Pengelolaan Hutan, Kemiskinan Masyarakat, Ulayat, Akses

\footnotetext{
1 Penelitian ini didanai oleh In Search of Balance (ISB) Schoolarship kerjasama University of Adger Norway dan Universitas Gadjah Mada

2 Pascasarjana Manajemen dan Kebijakan Publik, UGM, email: hidayatulfajri28@gmail.com

${ }^{3}$ Wilayah administrasi terendah di Sumatera Barat, setingkat dengan desa tetapi memiliki fungsi yang agak berbeda dengan desa.
} 


\section{PENDAHULUAN}

Pemerintah pada tahun 1999 mengeluarkan kerangka kerja penyusunan tata hutan yang mengacu pada Undangundang No 41 tahun 1999 tentang kehutanan, menggantikan Undang-undang sebelumnya tentang kehutanan yaitu Undang-undang No. 5 Tahun 1967. Proses tata hutan sendiri diatur pada pasal $22 \mathrm{UU}$ 41 tahun 1999 dan kemudian diperkuat dengan dikeluarkannya PP No. 6 tahun 2007 pasal 12, sehingga kawasan hutan kemudian dibagi menjadi Kawasan Hutan Konservasi, Kawasan Hutan Lindung, dan Kawasan Hutan Produksi.

Sumatera Barat -provinsi dari penelitian ini dilakukan- tidak terbebas dari peraturan pengelolaan hutan tersebut. Luas daerah Sumatera Barat yang sekitar 4.229.730 Ha (Dishut Prov. Sumbar, 2013) kemudian berdasarkan Keputusan Menteri Kehutanan Nomor 422/KptsII/1999 tanggal 15 Juni 1999 seluas \pm 2.600.286 Ha ditetapkan menjadi kawasan Hutan Negara dengan luas \pm 2.600.286 Ha. Jumlah luasan kawasan hutan negara itu kemudian direvisi kembali lewat SK Menhut No. 141/Menhut-II/2012 tanggal 15 Maret 2012 tentang Penunjukan Kawasan Hutan dan Perairan Provinsi Sumatera Barat, sehingga luasan kawasan hutan negara di Sumatera Barat berkurang sedikit menjadi sekitar 2.346.041 Ha. Luasan kawasan hutan tersebut meliputi
$56,34 \%$ dari keseluruhan luas daerah Sumatera Barat.

Luas hutan lindung di Sumatera barat yang seluas $792.114 \mathrm{Ha}$ tersebut, 114.061 Ha berada di Kabupaten Solok atau $14,40 \%$ dari keseluruhan jumlah hutan lindung di Sumatera Barat dan merupakan Kabupaten dengan area hutan lindung yang terluas (Dishut Provinsi Sumbar 2013). Data KPHL (Kesatuan Pengelolaan Hutan Lindung) Solok tersebut membagi Nagari di Kabupaten Solok dalam tiga wilayah, yaitu yang di kategorikan nagari yang berada di dalam kawasan, yaitu apabila diatas $60 \%$ wilayah nagarinya tersebut berupa kawasan hutan lindung. kemudian negari yang dikategorikan berada disekitar kawasan yaitu nagari yang daerahnya berada kurang dari $60 \%$ - 20\% berbentuk kawasan hutan lindung, sedangkan yang terakhir yaitu nagari yang berada diluar kawasan. artinya nagari yang wilayahnya kurang d ari $20 \%$ yang masuk kedalam hutan lindung.

Hutan dalam terminologi KPHL Solok tesebut adalah hutan yang dikuasai negara dalam bentuk hutan konservasi, hutan lindung ataupun hutan produksi. Sedangkan di nagari yang tidak termasuk ke dalam kawasan hutan negara maupun nagari yang berada dikawasan hutan lindung yang hutannya dijadikan hutan negara, hutan itu berbentuk tanah ulayat 
yang dikuasai secara bersama-sama oleh masyarakat dan kebanyakan sudah ditanami dengan tanaman keras atau tanaman tua.

Angka kemiskinan antara Nagari Garabak Data dengan Nagari Bukik Kanduang menjadi representasi dari keadaan itu. Di Nagari Garabak Data jumlah penduduk miskinnya mencapai 26,79\% hampir 9 kali lipat dari jumlah penduduk miskin di Nagari Bukik Kanduang yang jumlah penduduk miskinnya hanya 3,53\%. Kemiskinan yang lebih tinggi di kawasan hutan negara menjelaskan bahwa penguasaan negara terhadap hutan meningkatkan kemiskinan masyarakat. Hal ini diakibatkan oleh tidak diakuinya kepemilikan masyarakat terhadap hutan karena hak penguasaan hutan berada di tangan negara (Bolaane, 2004; Hitchcock \& Biesele, 2004; Magole, 2007; Magole, 2009). Disisi lain, pemerintah tidak mendistribusikan akses ke sumber daya penting lainnya sebagai mata pencaharian bagi masyarakat setempat (Peters, 1994).

Pengelolaan hutan oleh masyarakat menjadi jalan keluar dari permasalahan kehutanan yang dikuasai dan dikelola oleh negara, karena dapat mensejahterakan masyarakat, mengurangi deforestasi serta memelihara keanekaragaman hayati (Bowler, et. al, 2012). Oleh sebab itu, pengelolaan hutan oleh masyarakat memenuhi persyaratan sebagai pendekatan yang layak didalam mengelola hutan karena bermanfaat dalam melakukan perlindungan kepada hutan selain juga bermanfaat di dalam pengembangan masyarakat (Charnley dan Poe, 2007).

Community forestry merupakan istilah yang digunakan sebagai bentuk inisiatif pengelolaan hutan berbasis masyarakat yang terkait dengan lahan hutan privat (Best dan Wayburn, 2001), hutan yang dimiliki sebagai milik umum (Bray et al. 2005), dan hutan di lahan masyarakat adat (LTC/ IES 1995). Meskipun pengelolaan berbasis masyarakat tidak menjamin hasil konservasi (Menzies, 2007), namun ada bukti yang mendukung hipotesis bahwa kontrol lokal lebih besar atas pengelolaan hutan akan menghasilkan kehutanan lebih berkelanjutan secara ekologis (Charnley dan Poe, 2007).

Tujuan penelitian ini untuk memahami bentuk pengelolaa hutan dan menjelaskan dampak pengelolaan hutan terhadap kemiskinan di Nagari Garabak Data dan Nagari Bukik Kanduang. Secara umum pendekatan di dalam pengelolaan hutan dapat dibedakan menjadi dua bentuk perspektif utama yaitu, pengelolaan hutan yang dilakukan oleh negara (State-based Forest Management) dan pengelolaan hutan yang dilakukan 
oleh masyarakat (Community-based Forest Managemant).

Pertama, pengelolaan hutan oleh negara (state-based forest management) mengedepankan praktik pengelolaan hutan berbasis negara yang umumnya terfokus pada bentuk hutan produksi atau konservasi, dengan penekanan pada manajemen pusat yang kuat (sentralistik). Sehingga dapat dikatakan bahwa kebijakan ini mempertahankan kepemilikan negara dan hampir dapat dikatakan juga tanpa mengakui hak adat masyarakat setempat dan membatasi pemanfaatan hutan oleh masyarakat lokal (Roe dan Nelson, 2009). Dalam prakteknya, rencana rasional pemerintah cenderung tak mengakui lokalisme (Winarwan, 2012). Dengan persektif kebijakan yang terpusat pada negara (state-centered policy), dalam pengelolaan kawasan hutan negara (konservasi, lindung, dan produksi) yang terjadi adalah tidak diakui adanya bentuk-bentuk sosial yang berbasis lingkungan, seperti; kekayaan umum, manajeman komunitas dan pengetahuan lokal. Dalam hal ini, pendekatan kebijakan yang mengemuka adalah pendekatan yang berpusat pada negara (state-centered policy), bukan pendekatan yang berbasis masyarakat (society-based policy). Penerapan pendekatan kekuasaan seperti itu cenderung menimbulkan disharmoni hubungan antara masyarakat, negara dan hutan.

Kedua, pengelolaan hutan oleh masyarakat (community-based forest management) merupakan konsep pengelolaan hutan oleh masyarakat (pengelolaan hutan komunal, hutan kemasyarakatan atau pengelolaan hutan partisipatif) mulai diterapkan dalam konteks tertentu, tetapi dengan pembatasan yang spesifik terhadap penerapannya secara jamak. Di berbagai belahan dunia, hutan kemasyarakatan dan pengelolaan sumberdaya alam telah dipraktekkan oleh masyarakat setempat sejak zaman dahulu (Roe et al. 2005). Banyak terdapat definisi tentang Community forestry, antara lain definisi yang disampaikan oleh Curran dan M'Gonigle (1999) yaitu; pengelolaan berbasis pada penguasaan lokal atas, dan pemanfaatan keuntungan dari sumberdaya hutan lokal. Menurut Suharjito, dkk (2000), community forestry tidaklah berbeda dengan social forestry sehingga mereka mengembangkan satu bentuk yang disebut dengan social community forestry yaitu sistem pengelolaan hutan yang dilakukan oleh individu, komunitas, atau kelompok pada lahan negara, lahan komunal, lahan adat atau lahan milik (individual/rumah tangga) untuk memenuhi kebutuhan individu/rumah tangga dan masyarakat, serta diusahakan 
secara komersial ataupun sekedar subsistensi.

Singkatnya, upaya kehutanan masyarakat adalah suatu bentuk memberikan otoritas secara de jure dalam penggunaan sumber daya hutan dan manajemen untuk pengguna lokal dan masyarakat, yang mungkin sudah secara de facto memiliki hak terhadap hutan. Schlager dan Ostrom (dalam Agrawal dan Ostrom, 2001) menjelaskan bahwa sebenarnya individu dan kelompok dapat memiliki hak milik dan sumber daya menggunakan (mengelola dan memiliki) hutan. Alden-Wily mendukung bahwa pengelolaan hutan berbasis masyarakat merupakan suatu bentuk dimana partisipasi lokal menjadi lebih banyak bermakna dan efektif ketika populasi lokal tidak hanya merupakan pihak yang bekerja sama sebagai pengguna hutan tetapi lebih sebagai pengelola hutan dan bahkan kawasan hutan (Sam, 2011).

Kedua pendakatan sebelumnya menjelaskan intervensi pemerintah dalam pengelolaan sumberdaya hutan sama sekali tidak menjadikan segalanya menjadi lebih baik. Masyarakat lokal yang selama ini memperoleh pemenuhan kebutuhan dari hutan merasa disingkirkan dengan kebijakan-kebijakan yang ada. Kemiskinan yang timbul merupakan kemiskinan yang diciptakan oleh penguasa (negara). Selain itu, Dominasi pemerintah dalam hal ini penguasaan hutan membuat akses masyarakat terhadap sumberdaya hutan tidak lagi sebebas ketika hutan tersebut masih dimiliki oleh masyarakat. Ketika hutan sudah tidak lagi menjadi milik masyarakat, ketika itu pulalah kemiskinan muncul. Sebagai akibat dari negara yang menunjukkan kekuasaannya, masyarakat tidak memiliki peluang mendapatkan manfaat dari hutan (Purwandari, 2011).

\section{METODE}

Jenis penelitian ini menggunakan pendekatan kualitatif. Penelitian ini dilakukan dengan terjun langsung ke objek penelitian yaitu di Nagari Garabak Data dan Nagari Bukik Kanduang, Kabupaten Solok, Provinsi Sumatera Barat. Penelitian dilakukan mulai bulan februari hingga Mei 2015. Penelitian ini dilakukan dengan menetap di kedua Nagari. Selain itu, penelitian ini juga dilakukan di lingkup Pemerintahan Kabupaten Solok. Secara umum, data yang dikumpulkan berupa data primer dan sekunder. Data dan informasi yang dikumpulkan pada penelitian ini dapat digolongkan ke dalam tiga hal, yaitu: (1) data yang berhubungan dengan kebijakan pemerintah tentang pengelolaan hutan; (2) data yang berhubungan dengan kondisikondisi kemiskinan masyarakat di dalam hutan negara dan masyarakat. Teknik 
wawancara yang digunakan adalah semi terstruktur yang memungkinkan peneliti untuk lebih bebas tanpa terpaku kepada pertanyaan-pertanyaan yang telah ditetapkan. Penentuan sampel dalam penelitian ini menggunakan metode campuran, yaitu purposive sampling, dan juga dengan metode snowball sampling.

\section{HASIL DAN PEMBAHASAN}

Pengelolaan Hutan dan Kemiskinan Masyarakat Nagari Garabak Data

\section{Pengelolaan Hutan di Nagari} Garabak Data

Sejak Undang-undang Kehutanan No. 41 tahun 1999, akses masyarakat terhadap hutan menjadi sangat sulit. Akses masyarakat untuk melakukan pengelolaan terhadap hutan menjadi terlarang. Keberadaan entah itu ladang, atau parak masyarakat yang berada di dalam kawasan hutan lindung membuat masyarakat kesulitan terutama dikarenakan oleh ketakutan akan konsekuensi hukum yang akan mereka terima. Bagi masyarakat kecil seperti masyarakat Nagari Garabak Data, berurusan dengan hukum hanya akan semakin mempersulit kehidupan mereka yang juga sudah sulit.

Sebenarnya sebelum tahun 1999 wilayah Nagari Garabak Data juga sudah menjadi bagian dari kawasan hutan lindung. Menjadi permasalahan ketika pada tahun 1999 dengan Undang-undang yang mulai diterapkan secara ketat, masyarakat tidak pernah tahu bahwa sebelumnya nagari mereka sudah dari jauh waktu menjadi kawasan hutan lindung. Mereka hanya mengetahui bahwa batas antara hutan yang bisa mereka kelola dengan yang tidak adalah batas yang berupa jalan rantai. Sedangkan informasi yang menyatakan bahwa nagari mereka masuk hutan lindung tidak pernah mereka ketahui sampai tahun 1999. Padahal jika dilihat sebenarnya Nagari Garabak Data sudah dimasukkan ke dalam kawasan hutan lindung sejak peta tahun 1982.

Peraturan yang lebih ketat dari sebelumnya membuat kawasan hutan lindung menjadi benar-benar tertutup bagi masyarakat. Apalagi semenjak tahun 2005 hutan mejadi sesuatu yang sakral sehingga tidak bisa disentuh masyarakat. Pemerintah Kabupaten Solok pun seakan tidak terlalu peduli dengan keadaan yang seperti itu. Sebab, akan menjadi prestasi yang buruk bagi mereka jika kawasan hutan lindung menjadi rusak. Kebijakan permerintah yang cenderung represif itulah semakin memperparah keadaan masyarakat Nagari Garabak Data. Padahal bukan saja pelarangan menebang kayu yang berada di dalam kawasan hutan lindung yang berdampak terhadap ekonomi masyarakat 
Semenjak pelarangan untuk mengelola kawasan hutan lindung, tanah ulayat tidak lagi berfungsi sebagai mana fungsinya sebagai tempat berusaha masyarakat. Masyarakat yang sebelumnya mendapatkan akses terhadap kawasan hutan dan melakukan pengolahan terhadap kasil hutan (mengekstrak) seperti melakukan pemotongan kayu (yang mereka tanam), mengolah hasil parak ataupun menentukan cara pengelolaan yang sesuai dengan kearifan lokal mereka menjadi menghilang akibat kawasan hutan di kuasai oleh negara.

Pelarangan pengelolaan hutan oleh masyarakat tidak di iringi oleh pengelolaan oleh negara (pemerintah) dengan baik. Jika dirunut sejarahnya, maka pengelolaan di kawasan hutan lindung khususnya di luar Pulau Jawa baru diperbolehkan setelah dikeluarkannya PP No. 6 tahun 2007 jo PP No. 3 tahun 2008 tentang Tata Hutan, Penyusunan Rencana Pengelolaan Hutan, serta Pemanfaatan Hutan. Sebelumnya di dalam Undang-undang Pokok Kehutanan No. 5 tahun 1967 maupun undang-undang yang menggantikannya yaitu UU No. 41 tahun 1999 tentang Kehutanan, melarang setiap kegiatan yang berlangsung di dalam kawasan hutan lindung.

Pengelolaan kawasan hutan lindung yang harusnya di lakukan oleh KPHL (Kesatuan Pengelolaan Hutan Lindung)
Solok sebagai unit pengelola di tingkat tapak. Namun sebagai pelaksana KPHL Solok tidak berjalan dengan optimal. KPHL Solok yang seharusnya mampu memberikan kembali akses kepada masyarakat Nagari Garabak Data untuk mengelola hutan, sampai sekarang masih belum mampu diwujudkan. KPHL Solok yang sudah diresmikan dari tahun 2012, sampai sekarang nyaris tanpa kegiatan. Khususnya di Nagari Garabak Data, dari observasi peneliti, masyarakat bahkan tidak tahu tentang KPHL Solok dan peraturan yang sudah memberikan ruang bagi mereka untuk mengelola kawasan dengan skema-skema yang sudah ditetapkan. Kendala-kendala yang dihadapi oleh KPHL Solok dalam melakukan pengelolaan berupa kendala yang terkait permasalahan-permasalahan; teknis, aturan atau regulasi, dan anggaran. Selain juga perhatian yang kurang dari pemerintah Kabupaten Solok terlihat dari anggaran (anggaran operasional) yang diberikan untuk KPHL Solok rendah dan cenderung turun dari tahun ke tahun. Terlihat dari sejak KPHL Solok mulai beroperasi, anggaran yang di anggarkan pada tahun 2013 sebesar 45 juta, 2014 turun menjadi 40 juta, dan pada tahun 2015 semakin turun menjadi 30 juta. Dengan biaya yang hanya 30 juta setahun, tidak akan sanggup mengelola daerah yang luasnya lebih dari $110.000 \mathrm{Ha}$. 
Permasalahan-permasalahan teknis maupun non-teknis yang menggerogoti KPHL tentu sangat menggangu KPHL Solok untuk mewujudkan tujuannya agar dapat mengelola kawasan dengan lestari serta memberikan manfaat ekonomi kepada daerah dan meningkatkan kesejahteraan masyarakat khususnya yang memiliki ketergantungan dengan keberadaaan hutan. Tiga tahun semenjak pengesahan sebagai pengelola kawasan hutan lindung, praktis KPHL belum memiliki kegiatan apapun yang bentuknya pengelolaan kawasan.

Kegagalan pengelolaan hutan lindung oleh KPHL menghampakan kembali peluang yang didapatkan oleh masyarakat Nagari Garabak Data untuk mendapatkan akses mengelola hutan. Padahal tanpa KPHL masyarakat tidak memiliki celah untuk melakukan pengelolaan hutan secara legal karena akses kawasan yang tertutup bagi masyarakat. Masyarakat yang memiliki ketergantungan tinggi terhadap hutan karena selain berfungsi sebagai tempat aktivitas ekonomi masyarakat, hutan juga merupakan simbol dari adat karena merupakan bagian dari ulayat masyarakat Nagari Garabak Data. Tetapi, kemampuan masyarakat untuk mengelola berupa kemampuan untuk mengekstraksi sumber daya dan produk hutan untuk memenuhi kebutuhan ekonomi mereka menjadi berkurang atau malah nyaris hilang. Beberapa oknum pada kenyataannya memanfaatkan kondisi pengelolaan hutan yang kacau-balau itu dengan melakukan kegiatan di dalam kawasan hutan lindung untuk mencari keuntungan secara pribadi. Pengelolaan illegal itu berbentuk (illegal logging) dan penambangan liar (illegal mining).

2. Dampak Pengelolaan Hutan terhadap Kemiskinan Masyarakat Nagari Garabak Data

Penguasaan terhadap hutan yang dilakukan oleh negara (pemerintah) berarti penghilangan hak masyarakat terhadap kawasan tidak saja berdampak terhadap sumber ekonomi masyarakat yang dihilangkan tetapi juga menghilangkan hak-hak politik dan hukum masyarakat atas kawasan hutan. Seperti kebebasan mereka untuk mengambil hasil hutan, atau kebebasan mereka di dalam menentukan kebijakan yang seharusnya mereka ambil dan laksanakan terkait pengelolaan kawasan hutan.

Pelaksanaan pemungutan hasil hutan oleh masyarakat Nagari Garabak Data tersebut harus seijin pemegang hak penguasaan hutan dalam hal ini adalah Pemerintah, dan di dalam prosedurnya tidak hanya berada di pihak KPHL Solok tetapi juga perizinan dari kementerian kehutanan. Masyarakat yang secara 
peraturan sangat awam tentu mengalami kesulitan jika harus berurusan dengan hukum seandainya mereka melakukan pengolahan tanpa izin. Ketakutan seperti itu membuat masyarakat lebih memilih diam.

Selain adanya rasa takut masyarakat untuk mengekspresikan kepentingan mereka dampak yang berupa pemiskinan politik hukum adalah hilang atau ditutupnya akses masyarakat terhadap hutan. Baik akses yang berupa kontrol mereka terhadap kawasan hutan namun juga mencerabut hukum adat masyarakat yang mengatur pengelolaan kawasan hutan. Di Nagari Garabak Data, kawasan hutan itu berbentuk tanah ulayat yang dikuasai secara bersama oleh masyarakat. sehingga di dalam pengelolaannya masyarakat mengambil keputusan melalui musyawarah mufakat dan peran dari niniak mamak sangatlah besar. Tetapi perampasan hak masyarakat tersebut membuat semuanya menjadi terhilangkan.

Sedangkan dampak terhadap kondisi ekonomi masyarakat, hilangnya akses masyarakat terhadap hutan berdampak kepada hilangnya sumber mata pencaharian mereka yang ditandai dengan turunnya penghasilan masyarakat seharihari. Menurunnya penghasilan masyarakat berimplikasi terhadap meningkatnya jumlah masyarakat Miskin di Nagari Garabak Data. Jika ditarik garis perbandingan sejak pemerintah malarang masyarakat untuk "masuk hutan" secara ketat, tahun 2005, peningkatan masyarakat miskin nyaris menjadi dua kali lipat sampai sekarang, 10 tahun sejak pelarangan itu. Lonjakan jumlah masyarakat miskin yang sangat drastis tersebut menyiratkan bahwa masyarakat Nagari Garabak Data sangat memiliki ketergantungan dengan hutan. Hutan bagi mereka adalah sumber ekonomi, dan sumber keberlanjutan kehidupan mereka.

Pengambilalihan lahan tidak hanya merusak tatanan kehidupan masyarakat secara ekonomi dan politik, namun juga tatanan sosial dan budaya masyarakat Nagari Garabak Data. Sebab, bagi masyarakat hutan merupakan lambang supremasi adat mereka. Namun akibat dari penguasaan hutan oleh negara masyarakat tidak memiliki kemampuan mengembangkan kebudayaan atau mempertahankan tradisi yang selama ini menjadi bagian kehidupan sosial warga. Masyarakat Nagari Garabak Data kehilangan kawasan hutan yang harusnya secara bersama-sama mengakibatkan retaknya hubungan kekerabatan mereka.

Interaksi yang harusnya terjadi di dalam pengelolaan hutan secara bersamasama serta perasaan persaudaraan yang tersirami oleh kepemilikan secara bersama menjadi berkurang karena media yang menjadi salah satu simbol penjalin itu 
hilang karena dikuasai oleh negara. Penguasaan hutan oleh negara tersebut membuat menurunnya rasa solidaritas di antara masyarakat, rasa persaudaraan dan senasib sepenanggungan, serta pengabaian terhadap pengetahuan lokal masyarakat di dalam pengelolaan hutan. Hal tersebut kemudian berdampak signifikan terhadap kemiskinan masyarakat Nagari Garabak Data.

\section{Pengelolaan Hutan dan Kemiskinan}

\section{Masyarakat Nagari Bukik Kanduang}

1. Pengelolaan Hutan di Nagari Bukik Kanduang

Berbeda dengan kondisi yang ada di Nagari Garabak Data, di Nagari Bukik Kanduang penguasaan atas hutan berada di tangan masyarakat sehingga pengelolaan yang dilakukan berdasarkan kepada konsepsi yang ada di tengah masyarakat. Konsepsi dalam mengelola hutan di Nagari Bukik Kanduang adalah Konsepsi Komunalistik yang didasari pada konsepsi penguasaan ulayat atas sumber daya alam. Konsepsi ulayat sendiri merupakan penguasaan sumber daya alam secara komunal dari susunan masyarakat yang kolektif.

Penguasaan niniak mamak (pemangku adat) atas nama anakkemenakan (masyarakat Nagari Bukik Kanduang) bukan saja sebatas hutan, tetapi konsepsi ulayat di Nagari Bukik Kanduang, dan di Nagari-nagari Minangkabau keseluruhan sebenarnya bersifat holistik, baik itu pada ruang tanah, hutan, air, danau, dan laut. Sesuai dengan pepatah Minangkabau; "batapak aie, batanduak gunuang, ado nan punyo". Sehingga penguasaan Masyarakat Nagari (adat) atas hutan merupakan bagian dari penguasaan Masyarakat Nagari (adat) atas ulayat dan masyarakat berhak untuk melakukan pengelolaan atas hutan dan juga ekstraksi dari hasil hutan sehingga bisa dimanfaatkan untuk kegiatan ekonomi masyarakat.

Sistem penguasaan hutan yang berdasarkan kearifan lokal tersebut diatur menurut ketentuan hukum adat setempat telah lama ada. Dalam hukum adat Minangkabau, hal itu dikenal dengan istilah 'tanah ulayat'. Sebagaimana yang telah disinggung sebelumnya, tanah ulayat secara sederhana bisa diartikan sebagai satu kesatuan wilayah yang mempunyai hak, baik itu hak ulayat kaum, hak ulayat suku maupun hak ulayat nagari. Tanah ulayat bisa berupa hutan maupun parak (kebun), sawah dan fungsi lainnya, yang secara arif difungsikan oleh masyarakat adat sesuai dengan kebutuhan dan ekologi. Secara umum pembagian tanah ulayat di Nagari Bukik Kanduang dapat dibedakan menjadi: 
a. Tanah ulayat kaum, yaitu; Tanah ulayat kaum ialah tanah ulayat yang dimiliki oleh suatu kaum dengan penguasaan kepala kaum atau mamak kepala waris.

b. Tanah Ulayat Suku, yaitu; Tanah ulayat suku adalah tanah ulayat yang dimiliki oleh suatu suku dengan penguasaan kepala suku, penghulu suku.

c. Tanah Ulayat Nagari, yaitu; Tanah Ulayat Nagari adalah tanah ulayat yang dimiliki oleh seluruh"anak nagari” atau "anak kemenakan", dengan penguasaan penghulupenghulu suku yang ada di nagari bersangkutan.

Hutan yang masuk ke dalam tanah ulayat tersebut dikelompokkan kepada pembagian tanah ulayat seperti yang dijelaskan diatas. Namun bukan berarti antara ke tiga jenis tanah ulayat tersebut tidak saling terintegrasi. Sebab, masyarakat di Nagari Bukik Kanduang merupakan kesatuan yang terdiri dari kaum, suku dan Nagari. Masing-masing individu menjadi anggota kaum, suku dan juga nagari sekaligus. Penguasaan oleh masyarakat tersebut membuat masyarakat memiliki kontrol terhadap hutan, dengan artian bahwa masyarakat Nagari Bukik Kanduang selain bisa memanfaatkan hasil hutan untuk keperluan ekonomi mereka, selain itu masyarakat juga berhak untuk membuat aturan-aturan yang terkait dengan pengelolaan terhadap hutan.

Bagi Masyarakat Nagari Bukik Kanduang, Ulayat merupakan objek sumber daya alam yang dikelola secara komunal dan dikelola dengan membertimbangkan keberlanjutan antar generasi. Selain itu ulayat juga simbol pengikat hubungan kekerabatan Masyarakat Nagari atau dikenal dengan Sako Pusako (harta pusaka) sehingga posisi ulayat berfungsi secara ekonomi maupun secara sosial budaya. Prinsip inilah yang kemudian menjadi landasan bentuk pengelolaan hutan oleh Masyarakat Nagari Bukik Kanduang, dimana hutan merupakan cadangan sumber daya alam antar generasi di Nagari.

Pemanfaatan hutan oleh Masyarakat Nagari Bukik Kanduang sendiri diutamakan bagi perluasan lahan pertanian (clearing it for agriculture) dengan mempertimbangkan keberlangsungan dan keseimbangan alam, seperti dilihat dalam pepatah adat; Nan bancah ditamani banieh, nan kareh dibuek ladang (yang rawa dijadikan sawah, yang lahan atau tanah keras dijadikan ladang).

Pengelolaan lahan yang dilakukan disesuaikan dengan kondisi hutan di Nagari Bukik Kanduang. Yang berada pada wilayah perbukitan (ulayat kareh/ tanah keras), maka Perluasan lahan 
pertanian terhadap hutan diperuntukkan bagi Ladang dan Parak. Parak sendiri merupakan bentuk perladangan rakyat yang di tanami oleh tumbuhan keras seperti kayu meranti dan tanaman yang berurat tunggang lainnya, seperti karet dan kulit manis. Pola parak dan ladang ini lazim ditemui di Nagari Bukik Kanduang.

Parak yang diolah dengan beragam jenis tanaman ini bertujuan agar dapat dipanen sepanjang waktu secara bergiliran. Selain dapat menjanjikan nilai ekonomi jangka panjang dan berkelanjutan, pengelolaan parak juga berfungsi sebagai kawasan penyangga, itulah mengapa pengelolaan parak terfokus pada tanaman tua. Dalam parak, pola produksi dan perkembangan spesies mirip dengan yang terjadi pada ekosistem hutan alami. Ternyata pengelolaan hutan seperti ini bisa menjaga kelestarian hutan tanpa merusak ekosistem yang terdapat didalamnya. Pembukaan lahan untuk parak atau ladang dilakukan baik itu di ulayat kaum, ulayat suku maupun ulayat Nagari. Di ulayat kaum dan suku bukan hanya bisa dimanfaatkan oleh anggota kaum atau suku, namun juga pihak lain di luar kaum dan suku yang berguna untuk menghindari lahan-lahan kosong yang produktif.

Selain Pemanfaatan hutan dengan pola parak atau ladang oleh Masyarakat Nagari Bukik Kanduang sangat memperhatikan dampaknya terhadap lingkungan, malah kebanyalan berfungsi sebagai pengikat tanah agar tidak longsor. Selain itu di Nagari Bukik Kanduang terdapat aturan larangan untuk membuka lahan untuk parak atau ladang dengan pola pembakaran lahan. Aturan itu lebih berupa norma, meskipun tidak tertulis tetapi masyarakat secara sadar mematuhinya. Biasanya untuk membuka lahan baru dikerjakan secara bersama-sama oleh masyarakat terutama dari anggota kaum atau suku dari yang akan membuka lahan.

2. Dampak Pengelolaan Hutan Terhadap Kemiskinan Masyarakat Pengelolaan hutan di Nagari Bukik Kanduang tidak terlepas dari kemampuan mereka dalam melakukan kontrol terhadap kawasan hutan. Kontrol menjadi hal yang sangat penting karena dengan begitu masyarakat mendapatkan akses terhadap hutan baik itu berupa kemampuan untuk mengekspresikan kepentingan mereka terhadap hutan ataupun hak mereka dengan cara menguasai secara kolektif. Kemandirian masyarakat itu menjadi modal yang sangat berarti di dalam menekan jumlah kemiskinan masyarakat di Nagari Bukik Kanduang.

Kemampuan masyarakat untuk mengambil keputusan di dalam menentukan apa yang akan mereka lakukan menjadi satu hal yang penting 
sebab masyarakat lah yang mengetahui apa yang mereka butuhkan dan berapa yang mereka butuhkan. Musyawarah tersebut dilakukan baik itu yang bersifat yanah ulayat kaum, tanah ulayat suku dan tanah ulayat nagari. Di dalam praktiknya di Nagari Bukik Kanduang musyawarah yang terjadi bukan hanya satu arah dan juga bukan hanya di lakukan oleh lakilaki, tetapi juga mengikutsertakan perempuan dan anak-anak. Keberdayaan mereka secara politik dan hukum ini membuat masyarakat Nagari Bukik Kanduang bisa bertahan dari kemiskinan.

Sedangkan di bidang ekonomi, tanah ulayat di Nagari Bukik Kanduang, telah banyak dimanfaatkan oleh masyarakat untuk berbagai tujuan sosial dan ekonomi. Umumnya tanah ulayat kaum, dan tanah ulayat suku sudah dimanfaatkan antara lain untuk perumahan, fasilitas umum dan sosial, persawahan dan perkebunan, sedangkan tanah ulayat nagari biasanya masih berbentuk hutan belantara dan pemanfaatannya lebih kepada pemanfaatan hasil hutan bukan kayu berupa rotan, manau, madu lebah, dan beberapa dari hutan ulayat nagari juga berbentuk parak.

Selain itu, pekerjaan masyarakat yang sebagian besar relatif sama yaitu sebagai petani, dengan pengelolaan secara komunal membuat tingkat kesejahteraan masyarakat jika dilihat secara kasat mata hampir merata. Tolok ukur akses terhadap barang produksi dalam hal ini lahan, membuktikan bahwa akses yang sama terhadap sumber daya alam atau lahan membuat eksklusifitas akses terhadap ekonomi yang hanya memberikan manfaat hanya bagi segelintir orang atau kelompok bisa dihidarkan. Inilah yang menjadikan kesejahteraan masyarakat di Nagari Bukik Kanduang cenderung sama.

Di bidang sosial budaya, pengelolaan hutan yang dilakukan oleh masyarakat dengan cara komunalistik tidak terlepas dari rasa solidaritas, rasa persaudaraan dan rasa senasib masyarakat sehingga di dalam pengelolaan hutan tidak ada yang termarginalkan karena status kawasan tersebut yang dikuasai secara komunal. Selain itu Pengelolaan oleh masyarakat tersebut juga menggunakan pengetahuan lokal masyarakat. Sehingga adanya ruang terhadap pengetahuan lokal tersebut selain bermanfaat terhadap peningkatan kesejahteraab masyarakat juga berdampak terhadap kelestarian hutan.

Dalam pengelolaan hutan, masyarakat Nagari Bukik Kanduang, memegang aturan-aturan yang sudah ditentukan secara umum di Minangkabau. Hutan yang berbentuk tanah ulayat tersebut dikuasai secara komunal dan tidak bisa diperjualbelikan kecuali dengan 
syarat-syarat tertentu seperti yang sudah dibahas sebelumnya. Itu merupakan aturan yang berlaku umum di seluruh nagari yang ada di Minangkabau, termasuk Nagari Bukik Kanduang. Aturan itu juga menyasar tanah ulayat yang ada di dalam nagari, berupa tanah ulayat kaum dan tanah ulayat suku.

\section{SIMPULAN}

Berdasarkan hasil penelitian maka dapat disimpulkan bahwa penguasaan dan pengelolaan pemerintah terhadap hutan masyarakat dengan menjadikannya dalam bentuk kawasan hutan lindung berdampak terhadap kemiskinan masyarakat. Sebaliknya penguasaan disertai pengelolaan yang berada di tangan masyarakat lokal (komunitas) berhasil menekan kemiskinan. Penguasaan hutan oleh negara menyebabkan kemiskinan struktural masyarakat karena berdampak terhadap unsur kehidupan masyarakat yaitu bidang politik-hukum, ekonomi dan sosial-budaya. Kondisi itu termanfestasikan di Nagari Garabak Data di mana masyarakat mengalami ketakutan untuk mengekspresikan kepentingannya di dalam pemanfaatan hutan, hilangnya tempat bekerja dan pendapatan masyarakat, tidak terbukannya ruang masyarakat untuk berpartisipasi di dalam pengelolaan hutan.
Selain itu, penguasaan atau kontrol yang dilakukan oleh pemerintah juga tidak diiringi oleh pengelolaan yang berjalan dengan baik. Terlihat dari program KPHL Solok yang tidak berjalan diakibatkan oleh berbagai hal seperti; regulasi yang sering bertukar dan tumpang tindih, permasalan yang berkaitan dengan birokrasi, politik daerah dan anggaran.

Kondisi yang berbeda terjadi di Nagari Bukik Kanduang, dimana Hutan dikuasai dan dikontrol oleh masyarakat dalam bentuk tanah ulayat, baik itu berbentuk; tanah ulayat kaum, tanah ulayat suku, dan tanah ulayat nagari. Hal ini berdampak dalam membantu masyarakat untuk menekan angka kemiskinan. Sebab masyarakat memilki akses terhadap hutan di untuk memenuhi kebutuhan rumah tangga mereka seharihari, memberikan pendapatan dan kesempatan kerja, terjadinya pemerataan dari manfaat hutan, serta adanya partisipasi demokratis di dalam pengelolaan hutan.

Pengelolaan dilakukan secara komunal oleh masyarakat, tergantung kepada status dari tanah ulayat, baik itu berbentuk ulayat kaum, suku atau nagari. Pengelolaan yang dilakukan masyarakat dengan menggunakan kearifan lokal yang disebut dengan ba "parak" atau dalam istilah akademi -meskipun tidak terlalu mirip- disebut dengan agroforestry. 
Sehingga dapat disimpulkan bahwa kontrol yang berada di tangan masyarakat yang disertai dengan pengelolaan berdasarkan local genius masyarakat bukan saja berhasil mensejahterakan masyarakat tetapi juga memperhatikan keberlangsungan fungsi ekologi hutan.

\section{DAFTAR PUSTAKA}

Agrawal, Arun, and Elinor Ostrom. 2001. Collective Action, Property Rights, and Devolution of Forest and Protected Area Management. Collective Action, Property Rights and Devolution of Forest and Protected Area Management, 2001: 73-107.

Ahmad Maryudi. 2011. Kegagalan Pengelolaan Hutan Jawa. Jurnal Wacana Edisi 25 Tahun XIII 2011. Yogyakarta: Insisit Press

Awan Setya Dewanta, dkk (ed). 1999. Kemiskinan dan Kesenjangan di Indonesia. Yogyakarta: Aditya Media

Best, Constance. Laurie A Wayburnn. 2001. America's Private Forests: Status and Stewardship. Washington, DC: Island Press.

Blaikie, P and H. Brookfield (ed). 1986. Land Degradation and Society. London and New York: Methun Press

Bolaane, M, 2004. The Impact of Game Reserve Policy on The River BaSarwa/Bushmen of Botswana. Jurnal Social Policy and Administration. 399417.

Bowler, Diana E. Lisette M Buyung-Ali, John R Healey, Julia PG Jones, Teri M Knight dan Andrew S Pullin. 2012. Does community forest management provide global environmental benefits and improve local welfare?. Jurnal:
Frontiers in Ecology and the Environmentpp. 29-36

Bray, David. Borton. 2005. Community forestry in Mexico: twenty lessons learned and four future pathways. In: Bray, D.B., Merino-Pérez, L. and Barry, D. (eds.) The community forests of Mexico: managing for sustainable landscapes, 335-349. University of Texas Press, Austin, Texas.

Charnley, Susan and Melissa R. Poe. 2007. Community Forestry in Theory and Practice: Where Are We Now?. Jurnal: Annual Review of Anthropology. pp. 301-336

Curran, Deborah. Michael M'Gonigle. 1999. Aboriginal Forestry: Community Management as Opportunity and Imperative. Osgoode Hall Law Journal. 711-774

Deddy Winarwan. 2012. Kebijakan Pengelolaan Hutan, Kemiskinan Struktural dan Perlawanan Masyarakat Desa Hutan di Provinsi Lampung (Disertasi). Yogyakarta: Universitas Gadjah Mada

Hitchcock, RK and M, Biaselle 2004. San. Khwe, Basarwa, or Bushmen? Terminology, Identity, and Empowerment in Southern Africa, Kalahari Peoples Fund. http://www.kalaharipeoples.org/docum ents/San-term.htm

LTC (Land Tenure Cent.), IES (Inst. Environ. Stud.). 1995. Case Studies of Community-Based Forestry Enterprises in the Americas. Madison: Land Tenure Cent. Inst. Environ. Stud., Univ.Wis. Madison

Magole, Lefatshe I, 2007. The history of conservation evictions in Botswana: the struggle continues, with new hope. Jurnal Policy Matters of CEESP (Commission

on 
Environmental,Economic and Social Policy)

Magole, Lefatshe I. 2009. Common Pool Resource Management among San Communities in Ngamiland, Botswana. Jurnal Development Southern Africa Vol. 26, No. 4, October 2009

Menzies NK. 2007. Our Forest, Your Ecosystem, Their Timber: Communities, Conservation, and the State in Community-Based Forest Management. New York: Columbia Univ. Press

Peters, PE, 1994. Dividing the Commons: Politics, Policy, and Culture in Botswana. Charlottesville, VA: University Press of Virginia.

Roe, Dilys, and Fred Nelson. 2009. Chapter 2: The Origins and Evolution of Community- Based Natural Resource Management in Africa. Community Management of Natural Resources in Africa: Impacts, Experiences and Future Directions: 212.

Roe, Dilys. et al. 2005. PovertyConservation Linkages: A Conceptual Framework, Poverty and Conservation Learning Group. Jurnal: Sage, Akses: 10 Januari 2015

Sam, Thida. 2011. Community Forest Management. New York: United Nations Forum on Forests, UNFF9

Suhardjito, D. A Khan, W. A Djatmiko, M. T. Sirait dan S. Evelyna. 2000. Studi Kolaboratif FKKM Kehutanan Masyarakat. Yogyakarta: Aditya Media 